\title{
Perumusan Strategi Fakultas Teknik Universitas Suryakancana menggunakan Model Gabungan Balanced Scorecard, Sun-Tzu, Quality Function Deployment \& Analisis SWOT
}

\author{
Ali Subhan ${ }^{1}$ \\ ${ }^{1}$ Teknik Industri Universitas Suryakancana \\ Jl. Pasir Gede Raya, Cianjur \\ alisubhan72@yahoo.com
}

Dikirimkan: 11, 2107. Diterima: 12, 2017. Dipublikasikan: 12, 2017.

\begin{abstract}
The success of a college is influenced by various factors, both internal and external factors of the organization. Faculty of Engineering Suryakancana University is one of the many universities that manage higher education that must be able to survive from various challenges, obstacles and competition with other university institutions. This study aims to formulate the right strategy for Faculty of Engineering, Universitas Suryakancana able to compete with the existing universities in Cianjur and in the West Java Province. The method used in this research is by combining several methods among others Balanced Scorecard, Sun-Tzu, Quality Function Deployment, and SWOT Analysis. Based on the result of research there are several formulation of strategy that must be implemented by Faculty of Engineering Suryakancana University, among others the implementation of quality assurance system, improvement of lecturer's resources, strict student selection, sharpening of vision and mission of college, and implementation of internal supervision system.
\end{abstract}

Keywords: SWOT analysis, BSC, QFD, Sun-Tzu Strategy, Strategy Formulation

\begin{abstract}
Abstrak - Keberhasilan sebuah perguruan tinggi dipengaruhi oleh berbagai faktor, baik faktor internal maupun eksternal organisasi. Fakultas Teknik Universitas Suryakancana merupakan salah satu dari banyak lembaga perguruan tinggi yang mengelola pendidikan tinggi yang harus mampu bertahan dari berbagai tantangan, hambatan dan persaingan dengan lembaga perguruan tinggi yang lain. Penelitian ini bertujuan untuk merumuskan strategi yang tepat agar Fakutlas Teknik Universitas Suryakancana mampu bersaing dengan perguruan-perguruan tinggi yang ada di Kabupaten Cianjur dan di wilayah Provinsi Jawa Barat. Metoda yang digunakan dalam penelitian ini yaitu dengan menggabungkan beberapa metodaantara lain Balanced Scorecard, Sun-Tzu, Quality Function Deployment, dan Analisis SWOT. Berdasarkan hasil penelitian ada beberapa perumusan strategi yang harus dilaksanakan oleh Fakultas Teknik Universitas Suryakancana, antara lain penerapan sistem penjaminan mutu, peningkatan sumber daya dosen, melakukan seleksi mahasiswa dengan ketat, penajaman visi dan misi perguruan tinggi, dan penerapan sistem pengawasan internal.
\end{abstract}

Kata Kunci: SWOT analysis, BSC, QFD, Strategi Sun-Tzu, Formulasi Strategi

\section{Pendahuluan}

Persaingan bisnis menuntut organisasiuntuk secara terus-menerus melakukan perbaikan dan peningkatan mutu layanannya dalam mencapai customer value (nilai pelanggan) yang paling tinggi diantara para pesaingnya. Penelitian mengenai respon pelanggan dilakukan secara rutin oleh banyak organisasi untuk mengukur seberapa baik kinerja organisasinya dalam memberikan kepuasan kepada para pelanggannya. Hal ini dilakukan untuk mempertahankan pelanggan-pelanggan lama dan mendapatkan pelanggan-pelanggan baru dalam memperebutkan pasar yang kompetitif.

Keunggulan bersaing tidak mudah didapatkan oleh semua perusahaan. Lingkungan bisnisinternal maupun eksternal sangat berpengaruh sekali terhadap keberhasilan sebuah organisasi. Untuk mencapai keunggulan bersaing, suatu organisasi harus mampu merumuskan strategi yang tepat dalam mempertahankan kelangsungan bisnisnya diantara para pesaing yang sudah ada dan mengantisivasi munculnya pesaing-pesaing yang baru. Perumusan strategi 
diawali dengan melakukan analisis terhadap lingkungan bisnis (environment scanning).

Metoda yang umum digunakan dalam melakukan analisis lingkungan bisnis yaitu dengan SWOT analysis. Analisis SWOT dapat mengidentifikasi faktor-faktor eksternal yang berupa peluang maupun ancaman terhadap keberlangsungan bisnis, dan faktor-faktor internal yang berupa kekuatan maupun kelemahan yang ada pada perusahaan. Berdasarkan analisis SWOT dapat diketahui indikator-indikator utama untuk membuat formulasi rumusan strategi. Perumusan strategi perusahaan pada dasarnya dilakukan untuk mandapatkan suatu formulasi di mana terdapat keseimbangan antara kekuatan yang dimiliki perusahaan dan kelemahan yang ada pada perusahaan, sehingga mampu mengoptimalkan peluang dan mengantisivasi ancaman-ancaman yang muncul dari adanya pesaing-pesaing bisnis. Keseimbangan ini tentunya dapat diketahui melalui indikator-indikator kinerja utama perusahaan (key performance indicator).

Balance scorecard (BSC) merupakan sekelompok ukuran yang berkaitan langsung dengan strategi suatu perusahaan. BSC adalah alat yang digunakan untuk mengukur kinerja perusahaan yang dikembangkan [1] dengan memperhatikan 4 (empat) perspektif, yaitu kinerja keuangan, pengetahuan mengenai pelanggan, proses bisnis internal, serta pembelajaran dan pertumbuhan. BSC mengandung definisi yang tepat mengenai visi dan strategi perusahaan yang dapat digunakan sebagai tolok ukur kinerja perusahaan.BSC yang dibuat dengan baik akan menyeimbangkan ukuran jangka pendek dengan jangka panjang, ukuran keungan dengan non keuangan, serta perspektif kinerja internal dengan eksternal. BSC merupakan sistem manajemen yang dapat digunakan sebagai kerangka pengaturan utama untuk proeses-proses manajerial kunci dalam sebuah perusahaan.

Balanced scorecard dapat digunakan sebagai sistem kontrol sekaligus sistem revisi strategi perusahaan [2]. Sedangkan berdasarkan hasil penelitian empiris yang dilakukan [3], Balanced scorecard efektif digunakan untuk mengkomunikasikan dan mengendalikan strategi perusahaan.

Perkembangan selanjutnya, penelitian [4] menilai bahwa balance scorecard hanya dapat mengukur keefektifan strategi perusahaan.Balance scorecard tidak dapat digunakan untuk pembuatan keputusan strategi. Berdasarkan kritikan tersebut, [5] menyampaikan gagasan untuk memadukan analisis SWOT dengan konsep Balanced Scorecard. Penelitian [4] juga menilai bahwa konsep balanced scorecard hanya fokus pada upaya memberikan kepuasan pelanggan. Ia mengkritik bahwa balanced scorecard tidak dapat menjawab "bagaimana menterjemahkan keinginan pelanggan dan mewujudkannya dalam karakteristik mutu produk sesuai dengan keinginan pelanggan". Pendapat inilah yang kemudian memicu peneliti [5] untuk mengkaitkan konsep balanced scorecard dengan konsep Quality Function Deployment (QFD) dalam perumusan strategi perusahaan.

Quality Function Deployment (QFD) adalah pendekatan visual berdasarkan matriks sistematis untuk perencanaan produk dan jasa berkualitas. QFD didasarkan pada filosofi Total Quality Management (TQM) bahwa produk dan jasa berkualitas tinggi dibedakan dengan standarstandar kualitas yang melekat pada semua aktivitas siklus hidup. Spesifikasi kebutuhan kualitas dan penyebaran kualitas produk dan jasa dimulai seawal mungkin dalam siklus hidup. Jika diartikan secara langsung maka $Q F D$ adalah penyebaran fungsi mutu, sedangkan definisi dari $Q F D$ itu sendiri adalah merupakan suatu metoda perencanaan produk yang terstruktur dan juga merupakan metoda pengembangan yang memungkinkan tim pengembang suatu perusahaan untuk menjelaskan spesifikasi keinginan dan kebutuhan pelanggan sehingga kemudian mereka dapat mengevaluasi kelebihan dan kekurangan dari setiap produk atau jasa yang ditawarkan. Tujuan dari $Q F D$ adalah untuk menjamin bahwa produk yang menghasilkan dapat memenuhi tingkat kualitas yang diperlukan, sehingga benar-benar dapat memuaskan kebutuhan para pelanggan.

Konsep QFD berupaya memahami kebutuhan konsumen sebelum perusahaan menterjemahkannya ke dalam kesatuan atribut produk yang akan dihasilkan. Konsep QFD juga membandingkan atribut produk perusahaan dengan atribut produk pesaing untuk mengetahui keunggulan dan kelemahan setiap atribut produk yang akan dihasilkan perusahaan. Metodologi QFD ini dibagi menjadi berbagai langkah-langkah analitis, sebagian besar didokumentasikan dalam bentuk grafik. Proses QFD terdiri dari tiga langkah: kualitas desain, detail desain dan proses penyebaran. Proses QFD merupakan pengembangan mekanisme operasi untuk mengubah harapan pelanggan dalam persyaratan desain manufaktur yang spesifik [6]. Konsep QFD dijabarkan dalam House of Quality, suatu matriks yang terdiri dari "apa yang diinginkan pelanggan" (what) serta "bagaimana perusahaan memenuhi keinginan tersebut" (how). Berdasarkan publikasi hasil penelitian sebelumnya, menunjukkan bahwa penerapan konsep QFD terbukti mampu mengantarkan perusahaan meraih kesuksesan [7]. 


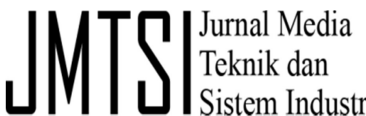

Selanjutnya, [5] mengembangkan formulasi strategi perusahaan dengan mengintegrasikan BSC ke dalam QFD. Dalam konsep QFD, BSC berada pada sumbu vertikal untuk mengetahui "apa yang diinginkan pelanggan" (what). Sedangkan untuk menjawab "bagaimana perusahaan memenuhi keinginan tersebut" (how) pada sumbu horizontal, penelitian [5] menggunakan strategi Sun-Tzu's. Strategi SunTzu's merupakan strategi militer dari sejarah kuno Cina yang sarat dengan nilai filosofi untuk memenangkan persaingan. Kepopuleran filosofi strategi Sun Tzu's menginspirasi beberapa pelaku bisnis dan akademisi untuk memperdalam strategi tersebut dan menerapkannya sebagai strategi bisnis dalam situasi persaingan yang sangat dinamis.

Pada akhirnya pemikiran Lee dan Ko menghasilkan formulasi sistem manajemen strategis baru yang lebih sistematis dan holistis. Sistem manajemen strategis ini menyeimbangkan strategi dalam pencapaian tujuan perusahaan dengan memperhatikan kebutuhan pelanggan yang pada akhirnya bertujuan memenangkan persaingan global. Sistem manajemen strategis ini memadukan antara Balanced Scorecard dengan Strategi Sun Tzu dalam metolodogi Quality Function Deployment.

Pada perkembangannya kemudian, hasil pemikiran [5] ini diperkuat oleh pendapat [8] yang menyatakan bahwa perpaduan antara strategi Sun Tzu's dan balanced scorecard sangat tepat jika diterapkan sebagai strategi bisnis modern. Perpaduan strategi ini diyakininya dapat membantu perusahaan dalam merumuskan strategi untuk memenangkan persaingan bisnis. Sebelumnya, penelitian [8] mengkritik bahwa filosofi Sun Tzu sebagian besar hanya membahas proses penetapan tujuan dan arah untuk mencapai sasaran. Strategi Sun Tzu tidak menjelaskan rincian pengukuran keberhasilan pencapaian tujuan. Hal ini karena dalam pertempuran kuno, hanya ada dua kriteria pencapaian tujuan, yaitu menang atau kalah. Tanpa penafsiran yang tepat ke lingkungan bisnis yang sebenarnya dalam jaman modern, strategi Sun Tzu itu hanya teori. Oleh karena itu, ia sangat mendukung pendapat [5] yang mengkombinasikan antara strategi Sun Tzu's untuk perumusan strategi bisnis dengan balanced scorecard sebagai penilai kinerja perusahaan.

Makalah ini membahas tentang perencanaan strategi Fakultas Teknik Universitas Suryakancana Cianjur (FT-UNSUR). FT-UNSUR berdiri pada tahun 2001, yang merupakan salah satu fakultas di lingkungan Universitas Suryakancana Cianjur, dan berada di bawah naungan Yayasan Pendidikan Suryakancana
Cianjur (YPS Cianjur). YPS Cianjur merupakan yayasan milik PEMDA yang berada di bawah pembinaan Pemerintah Daerah Kabupaten Cianjur. Saat ini FT-UNSUR menyelenggarakan program pendidikan berjenjang S1 dengan tiga program studi, yaitu Teknik Industri, Teknik Sipil dan Teknik Informatika.

Secara keseluruhan mahasiswa FT-UNSUR berjumlah sekitar 750 orang mahasiswa. Program studi yang paling banyak mahasiswanya adalah Teknik Informatika. Sebagai lembaga pendidikan tinggi yang masih baru, FT-UNSUR masih perlu melakukan perbaikan-perbaikan serta peningkatan baik dari program akademik, administrasi maupun kemahasiswaan. Visi dan misi FT-UNSUR yang telah dirumuskan saat ini belum sepenuhnya mencerminkan sebuah pencapaian target yang jelas. Penjabaran visi-misi FT-UNSUR ini belum menyentuh sampai ke program-program studi.

\section{Metodologi Penelitian}

Penelitian ini merupakan penelitian kualitatif untuk menggabungkan Balance Scorecard dan Sun Tzu ke dalam Quality Function Deployment berdasarkan SWOT Analysis dengan tahapan metode penelitian yaitu:

1) SWOT Analysis

2) Pengelompokan hasil SWOT Analysis menurut Balance Scorecard

3) Menghubungkan 4 Perspektif Balance Scorecard dengan Filsapat Sun Tzu

4) Menghubungkan 4 Perspektif Balance Scorecard dengan Filsapat Sun Tzu

\subsection{SWOT Analysis}

Analisis SWOT dilakukan dengan cara menentukan daftar faktor-faktor eksternal yang berpengaruh terhadap perusahaan dan industrinya yang berupa peluang maupun ancaman (OT). Berikan bobot untuk masing-masing faktor dari 0,0 (tidak penting) hingga 1,0 (paling penting). Bobot mengindikasikan tingkat penting relaif dari faktor terhadap keberhasilan perusahaan dalam suatu industri. Peluang seringkali diberi bobot lebih tinggi dari ancaman, tetapi ancaman juga dapat diberi bobot yang tinggi jika ancaman tersebut sangat serius. Bobot yang tepat dapat ditentukan dengan membandingkan keberhasilan atau kegagalan pesaing atau dengan mendiskusikan faktor dan mencapai konsensus kelompok. Penjumlahan dari seluruh bobot yang diberikan kepada semua faktor harus sama dengan 1,0. Berikan peringkat 1 hingga 4 untuk masingmasing faktor eksternal kunci tentang seberapa efektif strategi perusahaan saat ini dalam merespons faktor tersebut, di mana $4=$ respons perusahaan superior, $3=$ respons perusahaan di atas rata-rata, 2 = respons perusahaan rata-rata, 
dan $1=$ respon perusahaan jelek. Peringkat didasari pada efektivitas strategi perusahaan. Kalikan masing-masing bobot faktor dengan peringkatnya untuk menentukan nilai tertimbang. Jumlahkan nilai tertimbang dari masing-masing variabel untuk menentukan total nilai tertimbang bagi organisasi. Berikutnya tentukan daftar faktor-faktor internal yang merupakan kekuatan dan kelemahan (SW) yang dimiliki perusahaan, dan lakukan pembobotan serta perhitungan sekanjunya seperti pada faktor-faktor eksternal.

Analisis SWOT berguna untuk mencocokkan faktor-faktor internal dengan faktor-faktor eksternal sehingga menciptakan matriks strategis. Faktor-faktor internal berada di dalam kendali organisasi perusahaan, seperti operasi, keuangan, pemasaran, sumber daya manusia. Sedangkan faktor-faktor eksternal berada di luar kendali organisasi, seperti faktor politik, ekonomi, teknologi, kompetisi, dan kebijakan pemerintah. Matriks strategi SWOT diperlihatkan pada Tabel I.

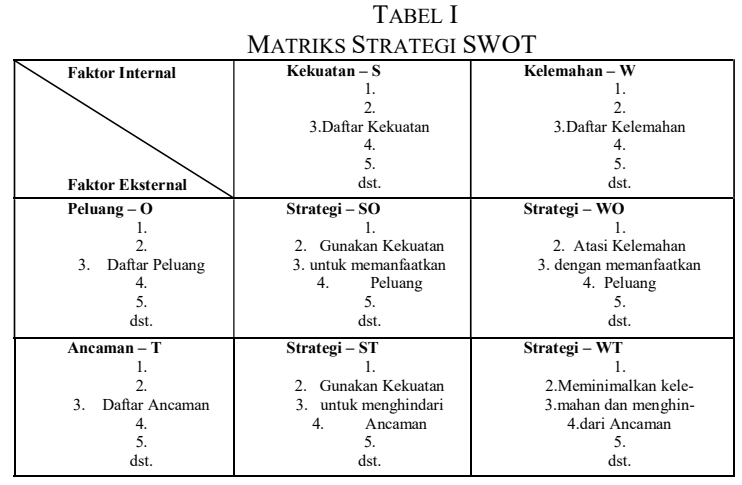

2.2 Pengelompokan hasil SWOT Analysis menurut Balance Scorecard

Langkah selanjutnya, berdasarkan hasil analisa SWOT maka dapat dikelompokan strategi-strategi menurut Balanced Scorecard. Pengelompokan strategi ini dimulai dari strategi SO, WO, ST sampai dengan strategi WT, sehingga dari berbagai strategi tersebut akan muncul indikatorindikator kinerja utama perusahaan berdasarkan perspektif kinerja keuangan, pengetahuan mengenai pelanggan, proses bisnis internal, serta pembelajaran dan pertumbuhan.

2.3 Menghubungkan 4 Perspektif Balance Scorecard dengan Filsafat Sun Tzu

Setelah diketahui indikator-indikator kinerja utama perusahaan berdasarkan 4 perspektif balanced scorecard di atas, selanjutnya mencari hubungan antara indikator kinerja dari ke empat perspektif tersebut dengan 13 point model seni perang Sun Tzu. Dalam model filsapat Sun Tzu terdapat 13 langkah strategi yang berkaitan dengan seni perang, yaitu:

1. Membuat Rencana (Laying Plans)

2. Berperang (Waging War)

3. Menyerang dengan Strategi (Attack By Strategy)

4. Pengaturan Taktik (Tactical Dispositions)

5. Energi (Energy)

6. Titik Kelemahan dan Kekuatan (Weak Point and Strong)

7. Manuver (Maneuvering)

8. Variasi dalam taktik (Variation in Tactics)

9. Pasukan pada barisan (The Army On The March)

10. Tanah Lapang (Terrain)

11. Sembilan Situasi (The Nine Situation)

12. Penyerangan dengan Api (The Attack By Fire)

13. Penggunaan mata-mata (The Use of Spies)

Dalam perkembangan selanjutnya filsafat Sun Tzu diterjemaahkan ke dalam bahasa bisnis dan manajemen seperti yang terdapat dalam [9] sebagaimana diperlihatkan pada Tabel II.

2.4 Menghubungkan 4 Perspektif Balance Scorecard dengan Filsapat Sun Tzu

Quality Function Deployment (QFD) adalah teknik yang memungkinkan perusahaan untuk mengantisipasi dan memprioritaskan kebutuhan pelanggan secara efektif dan menyeluruh, kemudian memasukkannya dalam atribut produk dan layanan perusahaan untuk pengguna akhir [10]. Sedangkan menurut [11], "Quality Function Deployment (QFD) merupakan suatu proses menetapkan keinginan pelanggan (apa yang diinginkan pelanggan) dan menterjemahkannya menjadi atribut (bagaimana) agar tiap area fungsional dapat memahami dan melaksanakannya.

TABEL II

TERJEMAhan Strategi ManaJemen Bisnis SunTzU

\begin{tabular}{|c|c|c|c|}
\hline (1) & Planning & (1) & $\begin{array}{l}\text { Planning of strategies, estimation } \\
\text { and leadership }\end{array}$ \\
\hline (2) & Competitive actions & (2) & Resources and competitive actions \\
\hline (3) & Competitive strategy & (3) & Competitive strategy and wisdom \\
\hline (4) & Positioning & (4) & $\begin{array}{l}\text { Positioning and targeting, strength } \\
\text { and weaknesses estimation }\end{array}$ \\
\hline (5) & Opportunity and timing & (5) & Opportunity, timing and management \\
\hline (6) & Control & (6) & $\begin{array}{l}\text { Control of market situations and } \\
\text { climate }\end{array}$ \\
\hline (7) & Managing direct conflict & (7) & $\begin{array}{l}\text { Management of conflict and avoid } \\
\text { confrontation }\end{array}$ \\
\hline (8) & Flexibility & (8) & Flexibility and adaptability \\
\hline (9) & Maneuvering & (9) & Observing and Maneuvering \\
\hline $\begin{array}{l}\text { (10) } \\
\text { (11) }\end{array}$ & $\begin{array}{l}\text { Type of competitive situations and } \\
\text { cause f failure } \\
\text { Competitive conditions and offensive } \\
\text { strategy }\end{array}$ & $\begin{array}{l}(10) \\
(11)\end{array}$ & $\begin{array}{l}\text { Competitive situations and causes of } \\
\text { failure } \\
\text { Competitive conditions and offensive } \\
\text { strategy, alliance and vision }\end{array}$ \\
\hline (12) & Destroying reputation & (12) & Destroying and decision \\
\hline (13) & Gathering intelligence & (13) & Intelligence and information \\
\hline
\end{tabular}

Sumber: [9] 


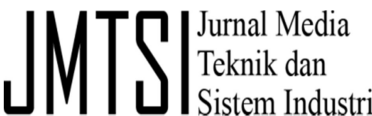

QFD menggunakan analisis matematis dalam serangkaian matriks house of quality (rumah kualitas) untuk menunjukkan hubungan fungsional antara kebutuhan konsumen dengan produk yang akan dihasilkan perusahaan. Melalui analisis hubungan dari berbagai komponen fungsional tersebut, seseorang mampu mengukur kualitas dan menetapkan prioritas. Sebenarnya, QFD bukan hanya alat tetapi juga sebuah proses perencanaan. QFD didefinisikan oleh Dr Yoji Akao sebagai: "mengubah tuntutan pelanggan menjadi karakteristik mutu produk dan mengembangkan desain kualitas untuk produk jadi dengan mengkaji hubungan sistematis diantara kedua unsur tersebut. Kajian dimulai dari penetapan kualitas masing-masing komponen fungsional dan menjabarkannya ke dalam kualitas masing-masing bagian dan proses."

Tujuan utama dari QFD adalah untuk meningkatkan kepuasan pelanggan melalui peningkatan kualitas produk dan menarik pelanggan melalui inovasi. QFD membantu sebuah organisasi membuat perencanaan yang efektif berkaitan dengan penentuan kualitas produk berdasarkan isu penting yang diharapakan pelanggan. Oleh karena itu, maka organisasi harus menggunakan proses QFD sebagai salah satu alat perencanaan utama mereka dalam penerapan Total Quality Management (TQM). Pemilihan prioritas dalam penetapan atribut produk dalam meningkatkan kepuasan pelanggan membantu perusahaan untuk fokus produk yang berbeda. Dalam aspek manajemen, QFD juga membantu:

a. Mengidentifikasi dan memprioritaskan kebutuhan pelanggan yang diperoleh dari berbagai sumber.

b. Menganalisis rincian desain dan perbaikan desain proses untuk memenuhi kebutuhan spesifikasi teknis.

c. Merangsang perbaikan secara terus-menerus.

d. Mendorong komunikasi dan membangun kerja sama tim dalam sebuah organisasi.

e. Mengurangi lead-time, mengoptimalkan sumber daya dan meningkatkan kualitas.

f. Membangun hubungan kemitraan dengan pelanggan.

Analogi yang paling sering digunakan untuk menggambarkan struktur $Q F D$ adalah "Rumah Kualitas" (House of Quality). Rumah kualitas adalah konstruksi pusat dari QFD. Matriks House of Quality adalah matriks perencanaan produk yang menggambarkan kebutuhan pelanggan, target perusahaan dan evaluasi produk pesaing. Matriks $H O Q$ menunjukkan hubungan antara kebutuhan-kebutuhan pelanggan dengan sifat-sifat rekayasa teknik. $Q F D$ adalah suatu cara untuk membantu tim membuat keputusan. Saat menggunakannya, tim mengembangkan sebuah model $Q F D$ yang berisi bagian-bagian yang dibuat dalam sebuah bagan yaitu Matriks House of Quality. Bagan House of Quality terdiri dari beberapa bagian, antara lain:

1. Menentukan suara pelanggan. Pada beberapa literatur biasa dinamakan sebagai "WHAT". What adalah sebuah daftar karakteristik dari produk atau jasa yang telah didefinisikan oleh pelanggan.

2. Menentukan bagaimana keinginan pelanggan bisa dipenuhi, yang dinamakan "HOW".

3. Selanjutnya diidentifikasi tingkat hubungan antara keinginan pelanggan (What) dengan cara bagaimana untuk meraihnya (How), yang dinamakan Relationship Matrix

4. Sisi bagian bawah House of Quality dinamakan daerahTARGET, yang merupakan hasil perhitungan perkalian antara bobot dari What dengan tingkat hubungan What dan How. Berdasarkan hasil perhitungan tersebut dapat diketahui urutan prioritas dalam mengimplementasikan How. Semakin tinggi nilainya maka semakin tinggi pula urutan prioritasnya.

5. Bagian atas House of Quality disebut "Correlation Matrix", menggambarkan hubungan internal dari How, hubungan yang digunakan berupa hubungan negatif dan positif. Bagian ini boleh dibuat atau tidak, tergantung kebutuhannya.

6. Kelima struktur di atas merupakan bangunan dasar atau basic dari house of quality. Ada bagian lain yang dikembangkan untuk menunjukan informasi tambahan yang dinamakan "Planning Matrix".

Dalam konsep QFD, balanced scorecard berada pada sumbu vertikal untuk mengetahui "apa yang diinginkan pelanggan" - (WHAT). Sedangkan untuk menjawab "bagaimana perusahaan memenuhi keinginan tersebut" (HOW) pada sumbu horizontal, maka digunakan strategi Sun-Tzu's. Model penggabungan ini dapat dilihat pada Gambar 1.

\section{HASIL PENELITIAN \& PEMBAHASAN}

Hasil dari penelitian ini terdiri dari:

1) Analisis SWOT

2) Hasil pengelompokan analisis SWOT ke dalam empat perspektif Balanced Scorecard

3) Hubungan antara keempat perspektif Balanced Scorecard dengan 13 falsafah Sun Tzu

4) Hasil penerapan QFD

\subsection{Analisis SWOT}

Berdasarkan hasil observasi, dihasilkan analisis faktor ekternal dan faktor internal seerti yang tercantum pada Tabel III dan Tabel IV. 
Faktor eksternal dan internal yang telah dirumuskan dan diberi bobot kemudian menjadi input untuk merumuskan strategi SO, ST, WO, dan WT pada matriks SWOT. Matriks SWOT tercantum pada Lampiran 1.

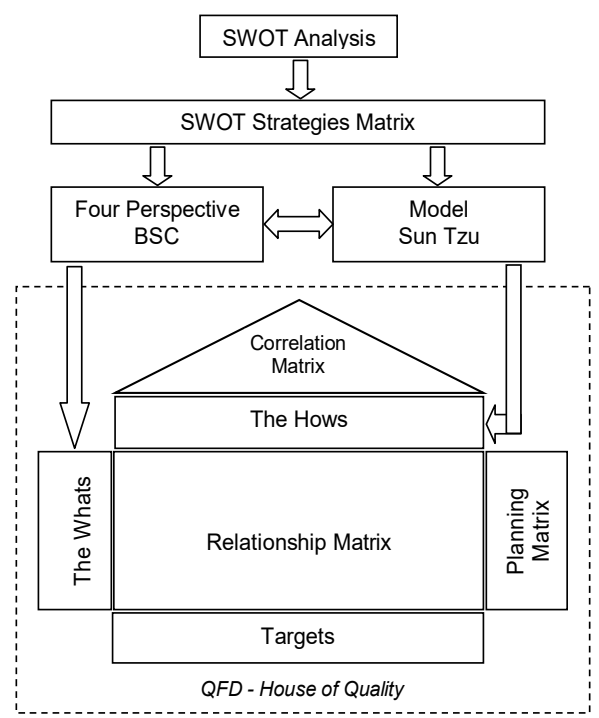

Gambar 1. Model Gabungan Balanced Scorecard, Sun Tzu dan QFD

TABEL III

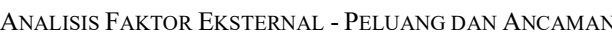
(OT) FT-UNSUR

\begin{tabular}{|c|c|c|c|}
\hline Faktor Eksternal Kunci & Bobot & Peringkat & $\begin{array}{r}\text { Nila } \\
\text { Tertimb }\end{array}$ \\
\hline \multicolumn{4}{|l|}{ Peluang } \\
\hline $\begin{array}{l}\text { 1. Jumlah calon mahasiswa terus meningkat dengan } \\
\text { bertambahnya SMA dan SMK di Kabupaten Cianjur }\end{array}$ & 0,20 & 3 & 0,60 \\
\hline $\begin{array}{l}\text { 2. Tingginya minat masyarakat Kabupaten Cianjur untuk } \\
\text { menyekolahkan anaknya ke jenjang perguruan tinggi }\end{array}$ & 0,05 & 2 & 0,10 \\
\hline $\begin{array}{l}\text { 3. Berangsur pulihnya perekenomian nasional, akan } \\
\text { mendorong kegiatan investasi yang pada gilirannya } \\
\text { akan membutuhkan tenaga kerja dari berbagai bidang }\end{array}$ & 0,10 & 2 & 0,20 \\
\hline $\begin{array}{l}\text { 4. Kurangnya tenaga pendidik di tingkat SLTP dan SLTA } \\
\text { di Kabupaten Cianjur membuka peluang kerja }\end{array}$ & 0,15 & 3 & 0,45 \\
\hline $\begin{array}{l}\text { 5. Banyak pegawai pemerintah maupun swasta yang } \\
\text { berminat meneruskan kuliah ke jenjang } S 1\end{array}$ & 0,05 & 2 & 0,10 \\
\hline $\begin{array}{l}\text { 6. Perkembangan Teknologi Informasi meningkatkan } \\
\text { minat lulusan SMA dan SMK untuk mendalami IT }\end{array}$ & 0,10 & 2 & 0,20 \\
\hline Faktor Eksternal Kunci & Bobot & Peringkat & $\begin{array}{r}\text { Nila } \\
\text { Tertimb }\end{array}$ \\
\hline \multicolumn{4}{|l|}{ Ancaman } \\
\hline $\begin{array}{l}\text { 1. Banyaknya perguruan tinggi di daerah maupun di } \\
\text { kota-kota lain memperebutkan calon mahasiswa }\end{array}$ & 0,10 & 2 & 0,20 \\
\hline 2. Kemampuan ekonomi masyarakat yang melemah & 0,05 & 3 & 0,15 \\
\hline $\begin{array}{l}\text { 3. Penambahan kuota penerimaan mahasiswa baru } \\
\text { di PTN mengurangi pangsa pasar PTS }\end{array}$ & 0,05 & 2 & 0,10 \\
\hline $\begin{array}{l}\text { 4. Munculnya perguruan-perguruan tinggi baru yang } \\
\text { memiliki daya saing lebih tinggi dari FTUNSUR }\end{array}$ & 0,10 & 2 & 0,20 \\
\hline $\begin{array}{l}\text { 5. Image masyarakat yang berpendapat bahwa } \\
\text { perguruan tinggi di kota lebih baik dari pada } \\
\text { perguruan tinggi di daerah }\end{array}$ & 0,05 & 2 & 0,10 \\
\hline
\end{tabular}

TABEL IV

ANALISIS FAKTOR INTERNAL - KEKUATAN DAN KELEMAHAN (SW) FT-UNSUR

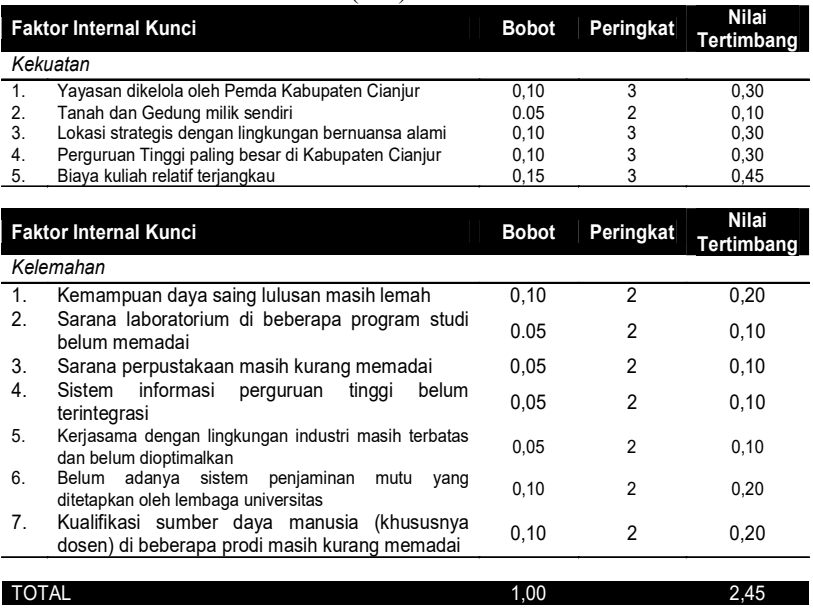

Berdasarkan matriks analisis SWOT maka strategi yang dirumuskan yaitu:

1) Strategi Kekuatan-Peluang (SO)

a) Gunakan bantuan pendanaan Pemerintah Daerah sebagai pengelola yayasan secara optimal untuk meningkatkan daya tampung penerimaan mahasiswa

b) Gunakan ketersediaan tanah dan gedung milik sendiri dengan keberadaan lokasi yang strategis dan bernuansa alamai secara optimal dalam memberikan pelayanan terbaik kepada mahasiswa

c) Gunakan keberadaan UNSUR sebagai perguruan tinggi terbesar di Kabupaten Cianjur dengan melakukan tata kelola perguruan tinggi yang lebih baik

d) Gunakan biaya kuliah yang relatif terjangkau untuk menerima mahasiswa baru sebanyak-banyaknya.

2) Strategi Kekuatan-Ancaman (ST)

a) Gunakan image UNSUR sebagai perguruan tinggi milik Pemda yang terbesar di Kabupaten Cianjur dengan sarana tanah dan gedung milik sendiri, dan keberadaan lokasi yang strategis dan bernuansa alami sebagai daya tarik dan menghindari calon mahasiswa daerah agar tidak kuliah ke perguruan tinggi di tempat lain

b) Gunakan kemampuan pendanaan Pemerintah Daerah sebagai pengelola yayasan secara optimal untuk memberikan subsidi kepada mahasiswa yang berprestasi 
c) Gunakan kemampuan pendanaan Pemerintah Daerah sebagai pengelola yayasan secara optimal untuk mengembangkan infrastruktur kampus sehingga keberadaan UNSUR sejajar dengan perguruan tinggi di kota lain yang sudah maju

3) Strategi Kelemahan-Peluang (WO)

a) Tingkatkan kemampuan daya saing lulusan dengan memanfaatkan peluang banyaknya jumlah calon mahasiswa baru melalui sistem seleksi penerimaan mahasiswa baru yang lebih ketat

b) Tingkatkan sarana laboratorium dengan memanfaatkan pungutan dana awal bagi mahasiswa baru.

c) Tingkatkan sarana perpustakaan melalui pungutan dana perpustakaan dari mahasiswa baru

d) Tingkatkan sumber daya dosen untuk mengikuti pendidikan ke jenjang yang lebih tinggi dengan mengalokasikan bantuan lembaga yang berasal dari mahasiswa

4) Strategi Kelemahan-Ancaman(WT)

a) Menajamkan visi dan misi perguruan tinggi

b) Menerapkan Sistem Penjaminan Mutu

c) Menerapkan Sistem Pengawasan Internal

d) Melakukan kerja sama dengan lingkungan industri dengan modelmodel workshop dan pelatihan

e) Meningkatkan citra perguruan tinggi melalui sistem informasi yang lebih baik

3.2 Pengelompokan Hasil Analisis SWOT ke dalam Empat Perspektif Balanced Scorecard

Strategi SWOT yang telah dirumuskan dikelompokan ke dalam empat perspektif Balanced Scorecard yang terdiri dari perspektif kinerja keuangan, perspektif pelanggan, perspektif proses bisnis internal, serta perspektif pembelajaran dan pertumbuhan.

\subsubsection{Perspektif Kinerja Keuangan}

Pada perspektif kinerja keuangan dikelompokan empat strategi, yaitu:

1) Gunakan bantuan pendanaan Pemerintah Daerah sebagai pengelola yayasan secara optimal untuk meningkatkan daya tampung penerimaan mahasiswa.

2) Gunakan biaya kuliah yang relatif terjangkau untuk menerima mahasiswa baru sebanyak-banyaknya.

3) Gunakan kemampuan pendanaan Pemerintah Daerah sebagai pengelola

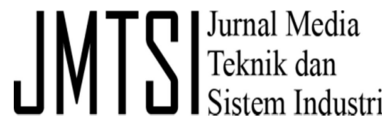

yayasan secara optimal untuk memberikan subsidi kepada mahasiswa yang berprestasi.

4) Gunakan kemampuan pendanaan Pemerintah Daerah sebagai pengelola yayasan secara optimal untuk mengembangkan infrastruktur kampus sehingga keberadaan UNSUR sejajar dengan perguruan tinggi di kota lain yang sudah maju

\subsubsection{Perspektif Pelanggan}

Pada perspektif pelnggan dikelompokan lima strategi, yaitu:

1) Gunakan ketersediaan tanah dan gedung milik sendiri dengan keberadaan lokasi yang strategis dan bernuansa alamai secara optimal dalam memberikan pelayanan terbaik kepada mahasiswa.

2) Tingkatkan sarana laboratorium dengan memanfaatkan pungutan dana awal bagi mahasiswa baru.

3) Tingkatkan sarana perpustakaan melalui pungutan dana perpustakaan dari mahasiswa.

4) Gunakan image UNSUR sebagai perguruan tinggi milik Pemda yang terbesar di Kabupaten Cianjur dengan sarana tanah dan gedung milik sendiri, dan keberadaan lokasi yang strategis dan bernuansa alami sebagai daya tarik dan menghindari calon mahasiswa daerah agar tidak kuliah ke perguruan tinggi di tempat lain.

5) Meningkatkan citra perguruan tinggi melalui sistem informasi yang lebih baik.

\subsubsection{Perspektif Proses Bisnis Internal}

Pada perspektif proses bisnis internal dikelompokan empat strategi, yaitu:

1) Tingkatkan kemampuan daya saing lulusan dengan memanfaatkan peluang banyaknya jumlah calon mahasiswa baru melalui sistem seleksi penerimaan mahasiswa baru yang lebih ketat.

2) Menajamkan visi dan misi perguruan tinggi.

3) Menerapkan Sistem Penjaminan Mutu.

4) Menerapkan Sistem Pengawasan Internal.

3.2.4 Perspektif Pembelajaran dan Pertumbuhan Pada perspektif pembelajaran dan pertumbuhan dikelompokan dua strategi, yaitu:

1) Tingkatkan sumber daya dosen untuk mengikuti pendidikan ke jenjang yang lebih tinggi dengan mengalokasikan bantuan lembaga yang berasal dari mahasiswa.

2) Melakukan kerja sama dengan lingkungan industri dengan model-model workshop dan pelatihan. 
3.3 Analisis Hubungan 4 Perspektif Balanced Scorecard dengan 13 Falsafah Sun Tzu

Filosofi Sun Tzu pada dasarnya memiliki 13 falsafah, ke-13 falsafah tersebut nantinya akan menjadi dasar dalam menganalisis hubungan antara perspektif Balanced Scorecard dengan filosofi Sun Tzu. Penerjamahan Falsafah Sun Tzu terhadap startegi bisnis UNSUR tercantum pada Tabel V.

TABEL V

PENERJAMAHAN FALSAFAH SUN TZU TERHADAP STRATEGI BISNIS UNSUR

B BISNIS UNSUR
\begin{tabular}{|l|l|l|}
\hline No. & \multicolumn{1}{|c|}{ Falsafah Sun Tzu } & \multicolumn{1}{|c|}{ Hasil Terjemaahan } \\
\hline 1. & Membuat Rencana & Menyusun Rencana Strategi Fakultas Teknik \\
\hline 2. & Berperang & Proses Akademik \\
\hline 3. & Menyerang dengan Strategi & Implementasi program sesuai rencana \\
\hline 4. & Pengaturan Taktik & Penetapan kebijakan (policy) dan SOP pekerjaan \\
\hline 5. & Energi & Mengoptimalkan segala sumber daya organisasi \\
\hline 6. & Titik Kelemahan dan Kekuatan & Evaluasi terhadap kinerja organisasi \\
\hline 7. & Manuver & Memanfaatkan core competency yang dimiliki \\
\hline 8. & Variasi dalam taktik & $\begin{array}{l}\text { Melakukan inovasi dan terobosan-terobosan melalui } \\
\text { kegiatan penelitian dan kemahasiswaan }\end{array}$ \\
\hline 9. & Pasukan pada barisan & $\begin{array}{l}\text { Promosi ke sekolah-sekolah dan sumber-sumber lain } \\
\text { yang memiliki potensi penyiapan calon mahasiswa baru }\end{array}$ \\
\hline 10. & Tanah Lapang & $\begin{array}{l}\text { Melaksanakan program CSR kampus dan konsolidasi } \\
\text { dengan pemerintah maupun perusahaan }\end{array}$ \\
\hline 11. & Sembilan Situasi & $\begin{array}{l}\text { Meningkatkan kualitas SDM dan pengembangan } \\
\text { sumber-sumber daya lainnya }\end{array}$ \\
\hline 12. & Penyerangan dengan Api & Penempatan SDM secara profesionalisme \\
\hline 13. & Penggunaan mata-mata & $\begin{array}{l}\text { Pengumpulkan informasi yang berkaitan dengan } \\
\text { peluang dan ancaman }\end{array}$ \\
\hline
\end{tabular}

Setelah diketahui indikator-indikator kinerja dari keempat perspektif balanced scorecard dengan hasil terjemaahan falsafah Sun Tzu, selanjutnya dicari hubungan antara keduanya dengan cara penyebaran kuesioner. Kuesioner disebarkan secara acak ke sejumlah responden dengan jumlah responden yang mencukupi (sesuai dengan test kecukupan data).

Hasil data dari kuesioner yang sudah diisi lengkap oleh responden selanjutnya diuji keabsahan dan keandalannya, yaitu dengan melakukan uji validitas dan uji reliabilitas. Dalam makalah ini data diasumsikan sudah valid dan dianggap reliable. Lampiran 2 menunjukan kuesioner yang diggunakan untuk analisis hubungan falsafah Sun Tzu dan Balanced Scorecard.

\subsection{Hasil Penerapan $Q F D$}

Setelah dilakukan proses pengolahan data kuesioner, selanjutnya indikator perspektif balanced scorecard dimasukan ke House of Quality pada metoda QFD sebagai WHAT, dan Strategi Sun Tzu dimasukan ke House of Quality pada metoda QFD sebagai $\mathrm{HOW}$.

Berdasarkan empat perspektif balanced scorecard diketahui komponen WHATs untuk QFD, yaitu:

A. Perspektif Kinerja Keuangan

1. Penggunaan bantuan pendanaan PEMDA secara optimal

2. Biaya kuliah yang relatif terjangkau

3. Pemberian Beasiswa dari Pemerintah Daerah Kab. Cianjur

4. PendanaanPEMDA bagi pengembangan infrastruktur kampus
B. Perspektif Pelanggan

1. Ketersediaan tanah, gedung milik sendiri dan lokasi strategis

2. Peningkatan sarana laboratorium dari dana mahasiswa baru

3. Peningkatan sarana perpustakaan dari dana mahasiswa baru

4. Image UNSUR sebagai perguruan tinggi Pemda terbesar

5. Peningkatan citra perguruan tinggi melalui sistem IT

C. Perspektif Proses Bisnis Internal

1. Seleksi mahasiswa dengan ketat

2. Penajaman visi dan misi perguruan tinggi

3. Penerapan Sistem Penjaminan Mutu

4. Penerapan Sistem Pengawasan Internal

D. Perspektif Pembelajaran dan Pertumbuhan

1. Peningkatan sumber daya dosen dari pendanaan mahasiswa

2. Kerja sama dengan industri melalui workshop dan pelatihan

Berdasarkan strategi-strategi Sun Tzu diketahui komponen HOWs untuk QFD, yaitu:

1. Menyusun Rencana Strategi Perguruan Tinggi

2. Melaksanakan proses akademik sesuai aturan Dirjen Dikti

3. Mengimplementasikan program sesuai Renstra

4. Menetapkan policy dan SOP administrasi dan akademik

5. Mengoptimalkan segala sumber daya organisasi

6. Mengevaluasi kinerja organisasi

7. Memanfaatkan core competency yang dimiliki

8. Inovasi dan terobosan-terobosan melalui kegiatan penelitian dan kemahasiswaan

9. Promosi ke sekolah-sekolah dan sumbersumber potensi mahasiswa baru

10. Melaksanakan program peduli kampus dan konsolidasi dengan pemerintah maupun perusahaan

11. Meningkatkan kualitas SDM dan pengembangan sumber-sumber daya lainnya

12. Menempatkan SDM secara profesionalisme

13. Mengumpulkan informasi yang berkaitan dengan peluang dan ancaman

Dari hasil analisis metoda QFD dapat diketahui urutan prioritas dari strategi yang harus dijalankan dalam mencapai WHATs. Prioritas karakteristik teknis (HOWs) merupakan skor atau nilai HOWs yang berfungsi menunjukkan prioritas mana yang harus diambil oleh pihak manajemen untuk 
diperbaiki yaitu dengan memulainya dari nilai yang terbesar. Prioritas HOWs merupakan output dari rangkaian seluruh proses dalam mendapatkan informasi dan tingkatan perumusan strategi pengembangan FT-UNSUR.

Bobot karakteristik teknis $(H O W s)$ diperoleh dengan mengalikan nilai rata-rata tingkat kepentingan pengguna (user) dengan nilai hubungan (relationship value) kebutuhan pengguna terhadap karakteristik teknisnya. Selanjutnya dijumlahkan untuk setiap karakteristik teknis.

Dalam melakukan pembobotan, dilakukan dua jenis pembobotan yaitu bobot mutlak (absolute weight) dan bobot relatif (relative weight). Bobot relatif adalah nilai relatif antara kriteria, dan diperoleh dengan cara membagi nilai bobot mutlak tiap karakteristik teknis dengan total nilai bobot karakteristik teknis.

Contoh untuk karakteristik teknis (How) yang berupa "Menyusun Rencana Strategi Perguruan Tinggi"'adalah sebagai berikut:

$$
\begin{aligned}
& \begin{aligned}
\text { Absolute Weight Score }= & (0.045 \times 5)+(0.085 \times 3)+(0.025 \times 1)+ \\
& (0.055 \times 3)+(0.035 \times 3)=2.62
\end{aligned} \\
& \begin{aligned}
\text { Total Absolute Weight }= & 2.62+3.16+2.56+2.10+\ldots+1.52 \\
= & 26.80 \\
\text { Relative Weight Score }= & (2.62 / 26.80) \times 100 \%=9.78 \%
\end{aligned}
\end{aligned}
$$

Berdasarkan hasil pemetaan dari House of Quality pada metoda Quality Function Deployment (QFD) diperoleh score prosentase untuk masingmasing perspektif balanced scorecard, yaitu:

a. Perspektif kinerja keuangan sebesar $20 \%$, terdiri dari:

- Penggunaan bantuan pendanaan PEMDA secara optimal sebesar 5\%

- Biaya kuliah yang relatif terjangkau sebesar $6 \%$

- Pemberian Beasiswa dari Pemerintah Daerah Kab. Cianjur sebesar 2\%

- Pendanaan PEMDA bagi pengembangan infrastruktur kampus sebesar 7\%

b. Perspektif pelanggan sebesar $25 \%$, terdiri dari:

- Ketersediaan tanah, gedung milik sendiri dan lokasi strategis sebesar $6 \%$

- Peningkatan sarana laboratorium dari dana mahasiswa baru sebesar $4 \%$

- Peningkatan sarana perpustakaan dari dana mahasiswa baru sebesar 5\%

- Image UNSUR sebagai perguruan tinggi Pemda terbesar sebesar 3\%

- Peningkatan citra perguruan tinggi melalui sistem IT sebesar 6\%

c. Perspektif proses bisnis internal sebesar 38\%, terdiri dari:

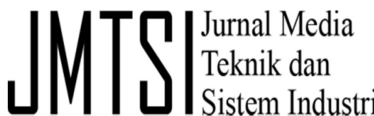

- Seleksi mahasiswa dengan ketat sebesar 9\%

- Penajaman visi dan misi perguruan tinggi sebesar 9\%

- Penerapan Sistem Penjaminan Mutu sebesar $11 \%$

- Penerapan Sistem Pengawasan Internal sebesar $9 \%$

d. Perspektif pembelajaran dan pertumbuhan sebesar $17 \%$, terdiri dari:

- Peningkatan sumber daya dosen dari pendanaan mahasiswa sebesar $10 \%$

- Kerja sama dengan industri melalui workshop dan pelatihan sebesar $7 \%$

Berdasarkan prosentasenya, maka proses bisnis internal FT-UNSUR harus mendapat perhatian yang paling serius karena memiliki bobot prosentase yang paling besar yaitu sebesar $38 \%$.

Dari keseluruhan perspektif balanced scorecard, maka dengan menekankan kepada 5 perspektif, secara berurutan hal-hal yang harus diperhatikan untuk mencapai keunggulan bersaing organisasi, yaitu:

1. Penerapan Sistem Penjaminan Mutu

2. Peningkatan sumber daya dosen

3. Melakukan seleksi mahasiswa dengan ketat

4. Penajaman visi dan misi perguruan tinggi

5. Penerapan Sistem Pengawasan Internal

Urutan prioritas yang harus dilaksanakan untuk pemenuhan target pencapaian kinerja perpektif balanced scorecard adalah sebagai berikut:

I. Melaksanakan proses akademik sesuai aturan Dirjen Dikti, dengan score bobot relatif sebesar $11,79 \%$

II. Menyusun Rencana Strategi FTUNSUR, dengan score bobot relatif sebesar $9,78 \%$

III. Inovasi dan terobosan-terobosan melalui kegiatan penelitian dan kemahasiswaan, dengan score bobot relatif sebesar 9,61\%

IV. Mengimplementasikan program sesuai Renstra, dengan score bobot relatif sebesar $9,55 \%$

V. Mengoptimalkan segala sumber daya organisasi, dengan score bobot relatif sebesar $9,46 \%$

VI. Menetapkan policy dan SOP administrasi dan akademik, dengan score bobot relatif sebesar 7,84\%

VII. Mengevaluasi kinerja organisasi, dengan score bobot relatif sebesar 7,35\%

VIII. Meningkatkan kualitas SDM dan pengembangan sumber-sumber daya lainnya, dengan score bobot relatif sebesar $6,75 \%$ 
IX. Memanfaatkan core competency yang dimiliki, dengan score bobot relatif sebesar $6,23 \%$

X. Promosi ke sekolah-sekolah dan sumbersumber potensi mahasiswa baru, dengan score bobot relatif sebesar $5,73 \%$

XI. Mengumpulkan informasi yang berkaitan dengan peluang dan ancaman, dengan score bobot relatif sebesar 5,67\%

XII. Melaksanakan program peduli kampus dan konsolidasi dengan pemerintah maupun perusahaan, dengan score bobot relatif sebesar 5,39\%

XIII. Menempatkan SDM secara profesionalisme, dengan score bobot relatif sebesar $4,83 \%$

\section{KESIMPULAN}

Berdasarkan analisis model penggabungan SWOT analysis, Balanced Scorecard dan Sun Tzu ke dalam metoda Quality Function Deployment, maka dalam merumuskan strategi organisasinya FT-UNSUR harus memperhatikan hal-hal sebagai berikut:

- Fokus perhatian untuk arah perbaikan dan pengembangan sebaiknya ditekankan pada proses bisnis internal.

- Terdapat lima indikator kinerja utama yang perlu mendapatkan perhatian yang serius yaitu:

a. Penerapan Sistem Penjaminan Mutu

b. Peningkatan sumber daya dosen

c. Melakukan seleksi mahasiswa dengan ketat

d. Penajaman visi dan misi perguruan tinggi

e. Penerapan Sistem Pengawasan Internal

- Sepuluh besar urutan prioritas strategi yang harus dilaksanakan lembaga untuk mencapai target kinerja organisasi yang optimal, yaitu:

1. Melaksanakan proses akademik sesuai aturan Dirjen Dikti.

2. Menyusun Rencana Strategi Perguruan Tinggi.

3. Inovasi dan terobosan-terobosan melalui kegiatan penelitian \& kemahasiswaan.

4. Mengimplementasikan program sesuai Renstra.

5. Mengoptimalkan segala sumber daya organisasi.

6. Menetapkan policy dan SOP administrasi dan akademik.

7. Mengevaluasi kinerja organisasi.

8. Meningkatkan kualitas SDM dan pengembangan sumber-sumber daya lainnya.
9. Memanfaatkan core competency yang dimiliki.

10. Promosi ke sekolah-sekolah dan sumbersumber potensi mahasiswa baru.

\section{REFERENSI}

[1] Kaplan, R.S. \& D.P. Norton. "The Balanced Scorecard - Measures That Drive Performance". Harvard Business Review January-February. 1992

[2] Campbell, D, S. Datar, S.C. Kulp, V. G. Narayanan. "Using the Balanced Scorecard as a Control System for Monitoring and Revising Corporate Strategy". Harvard NOM Working Paper No. 02-35. 2002

[3] Malina, M.A. and Selto, F.H. "Communicating and Controlling Strategy: An Empirical Study of the Effectiveness of the Balanced Scorecard". Journal of Management Accounting Research, 13, 47-90. 2001

[4] McAdam, R. \& E. O’Neil. "Taking a critical perspective to the European Business Excellence Model using a balanced scorecard approach: a case study in the service sector", Managing Service Quality: An International Journal, Vol. 9 Issue: 3, pp.191-197.1999

[5] S.F. Lee, \& A. Sai On Ko. "Building balanced scorecard with SWOT analysis, and implementing 'Sun Tzu's The Art of Business Management Strategies' on QFD methodology", Managerial Auditing Journal, Vol. 15, Edisi 1/2, Bradford, pg. 68. 2000

[6] Straker, D. "A Toolbook for Quality Improvement and Problem Solving". Prentice Hall. 1995

[7] Erikkson, I. \& F. McFadden. "Quality function deployment: a tool to improve software quality". Information and Software Technology. Vol. 35, Issue 9, September 1993, Pages 491-498. 1993

[8] Chih, E.\& Wen Cheng. "Recreating Sun Tsu's "Art of War" as a Strategy-oriented Balanced Scorecard for Business", Web Journal of Chinese Management Review, Vol. 6, No. 1, pp. 47-67. 2003

[9] Krause. D. G. "The Art of War for Executives" Tarcher Perigee. ISBN 9780399534102. 2007

[10] Wasserman, G. S. "On how to prioritize design requirements during the QFD planning process". IIE Transactions, 25(3), 59-65.1993

[11] Heizer, J. and B. Render. "Operations Management, 8th Edition". Pearson Prentice Hall. New Jersey. 2006 